\title{
Particulate organic matter and chlorophyll in the surface layer of the equatorial Pacific Ocean along $135^{\circ} \mathrm{W}$
}

\author{
M. Angélica Peña ${ }^{1}$, Marlon R. Lewis ${ }^{1}$, W. Glen Harrison ${ }^{2}$ \\ 1 Department of Oceanography, Dalhousie University, Halifax, Nova Scotia, Canada B3H 4J1 \\ ${ }^{2}$ Department of Fisheries and Oceans, Biological Oceanography Division, Bedford Institute of Oceanography, Box 1006 , \\ Dartmouth, Canada B2Y 4A2
}

\begin{abstract}
Vertical and horizontal distributions of chlorophyll (chl) a, phaeopigment, particulate organic carbon (POC) and nitrogen (PON) in the euphotic zone were studied on a transect across the equatorial Pacific at ca $135^{\circ} \mathrm{W}$ from $12^{\circ} \mathrm{S}$ to $15^{\circ} \mathrm{N}$. POC, PON, chl, and nutrient concentrations were highest near the equator. Despite a coincidence of maximum $\mathrm{POC}$, and PON levels with the subsurface chl maximum (SCM), photoadaptation appears to play the predominant role in the vertical distribution of chl along this equatorial transect. The size distribution of the above properties was examined within the mixed layer and SCM across the same transect. Small particles $(<10 \mu \mathrm{m})$ dominated at both depths. In general, phytoplankton cells constituted only a small proportion of the particulate organic matter, particularly in the $<1 \mu \mathrm{m}$ fraction which had higher proportions of detritus than the other fractions. The residence time of $\mathrm{POC}$ outside the equatorial region was $14 \mathrm{~d}$. In the equatorial upwelling region the residence time was shorter ( 6 to $7 \mathrm{~d}$ ), indicating that the suspended particles were turning over more rapidly. Results suggest that particulate loss by grazing is the predominant removal mechanism rather than advection or sedimentation. This suggestion is supported by the distributions of phaeopigment to chl a ratios, and the observed particle size distributions.
\end{abstract}

\section{INTRODUCTION}

The equatorial Pacific region has enhanced autotrophic production (Betzer et al. 1984, Chavez \& Barber 1987, Peña et al. 1990) due to large-scale divergence in the ocean circulation which increases concentration of plant nutrients in the euphotic zone. It has been estimated that this region could account for 10 to $56 \%$ of global new production (as defined by Dugdale \& Goering 1967, Chavez \& Barber 1987), and hence for a large part of the global downward flux of organic matter (Eppley \& Peterson 1979). A notable feature of this region is that, in spite of the high level of nutrients available, chlorophyll (chl) levels are low (Walsh 1976, Thomas 1979, Peña et al. 1990).

Despite its large area and the potential importance in the removal of atmospheric carbon through biological processes, there are relatively few biological data from the equatorial Pacific, in contrast to the more intensively studied subtropical ocean. In the equatorial Atlantic, the distribution of particulate organic carbon (POC) and its size structure has been well documented
(Herbland \& Le Bouteiller 1981, 1983). In the equatorial Pacific, it is only along $150^{\circ} \mathrm{W}$ that the distribution of POC has been reported (Wangersky 1976, Eppley et al. 1991). POC is a heterogeneous mix of living planktonic organisms and organic detritus. Detrital carbon consists mainly of fine particles, although larger particles of fecal material, crustacean molts, and aggregates of mucous-like material from gelatinous organisms are also present (Banse 1977). The living plankton usually account for less than half of the total POC collected by water bottle sampling (Sharp et al. 1980, Eppley et al. 1983). In the surface layer, the POC levels are a function of productivity (Wangersky 1976) and particulate organic matter (POM) composition is usually similar to that of phytoplankton (Copin-Montegut \& CopinMontegut 1983).

Information on the size composition of phytoplankton biomass is important for understanding the utilization of primary production in the surface layer and the flux of organic matter out of the surface layer. In tropical systems, size-fractionation studies (Herbland et al. 1985, Chavez 1989, Peña et al. 1990) have shown that 
chl concentrations are dominated by small organisms passing through a $10 \mu \mathrm{m}$ mesh screen. Together with the low chl and high production observed, this observation has led to the suggestion that equatorial upwelling systems may be more similar ecologically to subtropical systems, with a close coupling between rates of phytoplankton growth and zooplankton grazing and excretion, than to coastal upwelling zones, where grazing and recycling are relatively less important (Walsh 1976 , Minas \& Minas 1986, Murray et al. 1989, Peña et al. 1990).

In an attempt to better understand the distribution and dynamics of phytoplankton biomass in equatorial regions, the distribution of POM, chl $a$ and phaeopigment and their size-structure in the upper water column were investigated in a transect crossing the equatorial Pacific at $135^{\circ} \mathrm{W}$.

\section{METHODS}

Twelve stations were occupied by the RV 'Wecoma' in the equatorial Pacific Ocean along a transect crossing the equator within a few degrees of $135^{\circ} \mathrm{W}$ longitude and between $12^{\circ} \mathrm{S}$ and $15^{\circ} \mathrm{N}$ during April of 1988 (see Table 1). At each station, water samples were collected with twelve 5 I Niskin bottles on a rosette sampler to which the CTD was attached.

Duplicate water samples from 5 or 6 depths within the euphotic zone (between the surface and $150 \mathrm{~m}$ ) were obtained for POM and from 6 to 12 depths (between the surface and $200 \mathrm{~m}$ ) for total and sizefractionated chl. At 9 of the stations (Stns 20 to 78), duplicate water samples for size-fractionation of particulate matter were collected at two of these depths, one from the mixed layer region and another from the depth where the subsurface chl maximum (SCM) was expected, based on CTD cast.

Samples for total particulate organic carbon (POC) and nitrogen (PON) were obtained by filtering $1 \mathrm{l}$ of seawater through combusted glass fiber filters (What$\operatorname{man} G F / F)$. For the size fractionation 1 to 21 samples, depending on the quantity of particulate material, were passed through a $10 \mu \mathrm{m}$ or $1 \mu \mathrm{m}$ Nuclepore filter, and each filtrate was immediately filtered on a Whatman $\mathrm{GF} / \mathrm{F}$. After the filtration, the filters were stored at $-20^{\circ} \mathrm{C}$, then dried at $60^{\circ} \mathrm{C}$ and placed in a desiccator with silica gel until analysed with a Perkin Elmer elemental analyser (model 2400) calibrated with a cyclohexanone standard.

For total chl a measurements, $100 \mathrm{ml}$ of seawater were filtered through glass fiber filters (Whatman $\mathrm{GF} / \mathrm{F}$ ). Samples of $200 \mathrm{ml}$ were size-fractionated by passing the sample serially through a $10 \mu \mathrm{m}$ and a $1 \mu \mathrm{m}$ Nuclepore filter, and finally through a Whatman GF/F filter. The samples were then extracted with $10 \mathrm{ml}$ of $90 \%$ acetone for $24 \mathrm{~h}$ and the fluorescence was measured (Turner Design fluorometer) to derive chl a and phaeopigments values (Holm Hansen et al. 1965). The fluorometer was previously calibrated against pure chl a (Sigma). At 2 stations, comparisons were made of chl a concentration values obtained by following the filtration procedure used in the size-fractionation of POM, and by the chl size-fractionation procedure; the values from the 2 procedures agreed to within $5 \%$.

Nitrate samples were taken from 12 fixed depths at each station (between 0 and $200 \mathrm{~m}$ ) and determined by the method described by Strickland \& Parsons (1972) with an autoanalyser.

Chl a, POC and PON data were subjected to linear regression analysis (Model $\mathrm{II}_{i}$ as recommended by Laws \& Archie 1981) after pooling the data by: (1)

Table 1. Latitudinal distribution of average concentrations of chlorophyll (chl) a, particulate organic carbon (POC) and nitrogen (PON) at each station sampled

\begin{tabular}{|c|c|c|c|c|c|c|c|c|}
\hline \multirow[t]{2}{*}{ Stn } & \multicolumn{2}{|c|}{ Location } & \multicolumn{2}{|c|}{$\operatorname{POC}(\mu \mathrm{M})$} & \multicolumn{2}{|c|}{ PON $(\mu \mathrm{M})$} & \multicolumn{2}{|c|}{ Chl a $\left(\mu \mathrm{g} \mathrm{I}^{-1}\right)$} \\
\hline & Latitude & Long. (W) & Avg. & $\mathrm{SD}$ & Avg. & $\mathrm{SD}$ & Avg. & $\mathrm{SD}$ \\
\hline 11 & $12^{\circ} 09.4^{\circ} \mathrm{S}$ & $134^{\circ} 19.5^{\circ}$ & 7.9 & 3.7 & 1.01 & 0.6 & 0.22 & 0.06 \\
\hline 20 & $5^{\circ} 58.0^{\prime} \mathrm{S}$ & $134^{\circ} 59.4^{\prime}$ & 4.1 & 1.3 & 0.62 & 0.3 & 0.23 & 0.08 \\
\hline 34 & $1^{\circ} 59.9^{\mathrm{S}}$ & $133^{\circ} 00.2^{\prime}$ & 5.1 & 1.7 & 0.66 & 0.2 & 0.26 & 0.16 \\
\hline 39 & $0^{\circ} 59.9^{\prime} \mathrm{S}$ & $133^{\circ} 355^{\circ}$ & 5.8 & 2.1 & 0.77 & 0.3 & 0.35 & 0.13 \\
\hline 50 & $0^{\circ} 30.8^{\prime} \mathrm{N}$ & $133^{\circ} 18.8^{\prime}$ & 6.1 & 1.9 & 0.96 & 0.5 & 0.40 & 0.12 \\
\hline 55 & $2^{\circ} 03.0 \mathrm{~N}$ & $133^{\circ} 37.9^{\circ}$ & 6.4 & 2.3 & 0.85 & 0.3 & 0.36 & 0.11 \\
\hline 60 & $4^{\circ} 17.2 \mathrm{~N}$ & $133^{\circ} 30.5^{\prime}$ & 5.6 & 1.3 & 0.62 & 0.2 & 0.33 & 0.07 \\
\hline 65 & $5^{\circ} 45.1 \mathrm{~N}$ & $135^{\circ} 00.0^{\prime}$ & 5.5 & 0.7 & 0.75 & 0.4 & 0.31 & 0.09 \\
\hline 73 & $7^{\circ} 13.7^{\circ} \mathrm{N}$ & $137^{\circ} 33.3^{\prime}$ & 5.7 & 0.7 & 0.78 & 0.2 & 0.30 & 0.03 \\
\hline 78 & $9^{\circ} 03.4 \mathrm{~N}$ & $136^{\circ} 47.5^{\circ}$ & 5.3 & 1.0 & 0.46 & 0.1 & 0.27 & 0.08 \\
\hline 88 & $11^{\circ} 05.2^{\circ} \mathrm{N}$ & $136^{\circ} 26.8^{\prime}$ & 7.1 & 0.3 & 0.87 & 0.3 & 0.29 & 0.13 \\
\hline 96 & $15^{\circ} 40.9^{\circ} \mathrm{N}$ & $143^{\circ} 05.7^{\prime}$ & 6.8 & 0.3 & 0.77 & 0.3 & 0.11 & 0.03 \\
\hline
\end{tabular}


regions according to the nitrate available in the water, (2) size of the organisms, or (3) by grouping all data available.

\section{RESULTS}

\section{Distribution of chl, POC and PON}

The average concentrations of chl $a, P O C$ and PON in the euphotic zone along the transect are summarized in Table 1. The geographic variation of POC and PON concentrations was similar. For both, the variation was about 2 -fold (range 4.1 to $7.9 \mu \mathrm{M}$ of POC and 0.46 to 1.01 $\mu \mathrm{M}$ of PON) between $12^{\circ} \mathrm{S}$ and $15^{\circ} \mathrm{N}$, and both showed highest values near the equator and at the most poleward stations. In contrast, chl a concentration showed an increase coincident with POM concentration only near the equator. Details of the chlorophyll distribution along this transect were given by Peña et al. (1990).

The vertical profiles of suspended particulate matter (POC and PON) and chl a (Fig. 1) at each station share several features. Subsurface maxima were observed in some of the stations along the transect, although they were less prominent for POC and PON than for chl. The concentration of chl a at the maximum ranged from 0.26 to $0.59 \mu \mathrm{g}^{-1}$ and was, on average, about twice (range $=1.2$ to 4.0 ) that in the overlying waters. POC concentrations ranged from 5.05 to $13.09 \mu \mathrm{M}$ and were, on average, only about 1.3 (range $=1$ to 2.2 ) times the values of the upper layer. Near the equator (Stns 34 to 55), the subsurface POM maxima were more pronounced and located around 30 to $60 \mathrm{~m}$ in the vicinity of the SCM. Out of the equatorial zone, no coincidence between POC and chl maxima was observed.

Considering the entire transect, linear regression analysis (Table 2) gave $\mathrm{C} / \mathrm{N}$ molar ratios of 5.7 in the particulate matter (slightly lower than the Redfield ratio of 6.6 ). When the data were grouped by regions according to nutrient status - equatorial region (Stns 20 to 55 , with elevated nutrient concentration at the surface $(>4 \mu \mathrm{M})$ ) and outside the equatorial region (Stns 11 and 60 to 96 , where nutrient was depleted) - similar ratios (5.8 and 5.4 respectively) were estimated. The correlation coefficients were high ( $\mathrm{r}=0.82$ to 0.86 ) for both regression lines. In contrast, a significant linear regression model of POC or PON on chl a $(\mathrm{p}<0.01$ and $<0.5$ respectively) was obtained only for the equatorial region. The slope of $\mathrm{POC}$ on chl a regression (Table 2) was $178(w / w)$ and that of PON on chl a was $36(w / w)$. The differences in absolute magnitude of correlation coefficients between POC vs PON and POC or PON vs chl found between the regions indicate that compositional variability in the POM is occurring over the latitudinal range studied.

\section{Size distribution of POM in the mixed layer and SCM}

The latitudinal variation in the size distribution of POC and PON at 2 depths in the euphotic zone between $6^{\circ} \mathrm{S}$ and $9^{\circ} \mathrm{N}$ is shown in Fig. 2. In general, the biomass within all size-fractions increased in the region of the equator. The only exception occurred at $1^{\circ} \mathrm{S}$ (Stn 39) at the SCM depth, which was in fact a POC and PON minimum (Fig. 1). An unusual feature of the data was that the greatest POC concentrations occurred at the SCM depth whereas the greatest concentrations of PON were found within the mixed layer. Most of the latitudinal variation in POC and PON appeared to be associated with variations in the $<10 \mu \mathrm{m}$ size-fraction.

The relative contributions of each size-fraction to total biomass at each depth horizon is shown in Fig. 3. At all the stations sampled, most of the POM $(>70 \%$ of POC and $>50 \%$ of $\mathrm{PON}$ ) passed through a $10 \mu \mathrm{m}$ pore

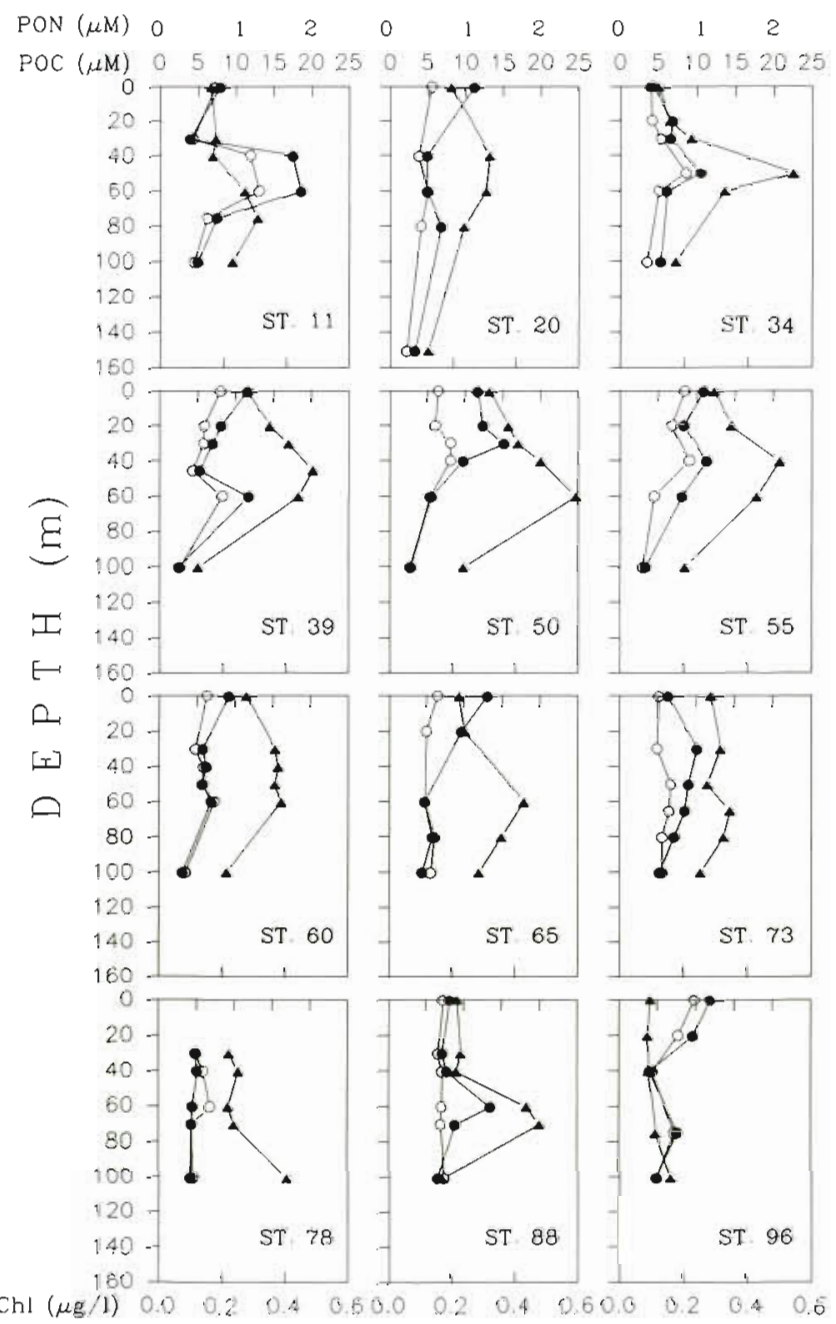

Fig. 1. Vertical profiles of chlorophyll (4), particulate organic carbon (POC; $\bullet$ ) and nitrogen (PON; o) at each station 
Table 3. Linear regression between POC, PON and chl a for each size-fraction, all data combined $(\mathrm{n}=18)$

\begin{tabular}{|c|c|}
\hline Regression lines & $\begin{array}{l}\text { Correlation } \\
\text { coefficient }\end{array}$ \\
\hline \multicolumn{2}{|l|}{ Total } \\
\hline 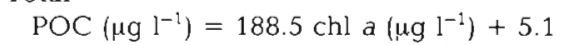 & $0.61 \cdots$ \\
\hline $\operatorname{PON}\left(\mu \mathrm{gl}^{-1}\right)=38.6 \mathrm{chl} \mathrm{a}\left(\mu \mathrm{g} \mathrm{l}^{-1}\right)-2.1$ & 0.35 \\
\hline $\mathrm{POC}(\mu \mathrm{M})=5.8 \mathrm{PON}(\mu \mathrm{M})+1.2$ & $0.65^{\cdots}$ \\
\hline \multicolumn{2}{|l|}{$<10 \mu \mathrm{m}$} \\
\hline $\operatorname{POC}\left(\mu \mathrm{g} \mathrm{l}^{-1}\right)=165.0 \mathrm{chl} \mathrm{a}\left(\mu \mathrm{g} \mathrm{l}^{-1}\right)+17.4$ & $0.44^{\circ}$ \\
\hline PON $\left(\mu \mathrm{gl}^{-1}\right)=39.8 \mathrm{chl} a\left(\mu \mathrm{g} \mathrm{l}^{-1}\right)-1.8$ & $0.51^{\bullet}$ \\
\hline $\mathrm{POC}(\mu \mathrm{M})=4.9 \mathrm{PON}(\mu \mathrm{M})+2.0$ & $0.75^{\cdots}$ \\
\hline \multicolumn{2}{|l|}{$<1 \mu \mathrm{m}$} \\
\hline $\mathrm{POC}\left(\mu \mathrm{g} \mathrm{l}^{-1}\right)=150.0 \mathrm{chl} a\left(\mu \mathrm{g} \mathrm{l}^{-1}\right)+22.7$ & 0.04 \\
\hline $\mathrm{PON}\left(\mu \mathrm{g} \mathrm{I}^{-1}\right)=37.7 \mathrm{chl} \mathrm{a}\left(\mu \mathrm{gl} \mathrm{l}^{-1}\right)+0.94$ & 0.23 \\
\hline $\mathrm{POC}(\mu \mathrm{M})=5.1 \mathrm{PON}(\mu \mathrm{M})+1.5$ & 0.41 \\
\hline \multicolumn{2}{|l|}{$\cdots$ Highly significant $(p<<0.01)$} \\
\hline - Significant $(\mathrm{p}<0.05)$ & \\
\hline
\end{tabular}

filter. In both small size-fractions $(<10$ and $<1 \mu \mathrm{m})$, greater proportions of POC were found within the mixed layer than at the SCM, except at Stns 39 and 78. In contrast, the contribution of PON showed the opposite tendency, with higher contributions of both sizefractions at the depth of the SCM and with higher variability along the transect than that of POC.

The POC on PON linear regression analysis (Table 3 ) yielded a slope of 5.8 for unfractionated samples and a lower value (4.9) for the $<10 \mu \mathrm{m}$ size-fraction. Both regressions showed a positive intercept. The slope of the POC on chl a regression was $188(\mathrm{w} / \mathrm{w})$ for unfractionated samples. No significant correlations were associated with the POC on chl a regression for the $<10 \mu \mathrm{m}$ size-fraction or with any regression for the $<1 \mu \mathrm{m}$ sizefraction.

\section{Relationship between POM and nutrient concentration}

In Fig. 4 the ratios of POC/PON, POC/chl $a$ and PON/ chl a have been averaged in 4 groups according to the amount of nitrate present: (1) the upper euphotic zone out of the equatorial region, (2) the upper euphotic zone at the equatorial upwelling region, (3) the lower nutrient containing part of the euphotic zone out of the equatorial region, and (4) this level within the equatorial region. Similar trends were observed in variation in the POC/chl and PON/chl with changing nitrate concentration. Both ratios tended to decrease with an increase of nitrate in the environment. The POC/PON ratio, in contrast, showed a slight increase at higher nitrate concentrations. Higher variability in the ratios was found outside the equatorial region compared with ratios in the equatorial region.

\section{Distribution of chl a to phaeopigment ratio}

Chl a was the most abundant pigment along the transect with the exception of deep in the water column, where phaeopigment dominated. This is evident in the vertical section (Fig. 5) of the ratio of the 2 pigments, chl a/phaeo, which ranged in value from 0.8 to 4 with values higher than 1.4 above the $60 \mathrm{~m}$ depth horizon. In the upper layer, lowest values were found south of $4^{\circ} \mathrm{S}$ with highest north of $10^{\circ} \mathrm{N}$; intermediate, more vertically variable values were observed at latitudes between those.

The vertical distribution of the ratio $\mathrm{chl} a /$ phaeo (Fig. 6) showed a similar trend in both regions, reaching highest values in the top $30 \mathrm{~m}$ and then decreasing with depth. However, lower average ratios (1 to 2.8 ) were found in the upper $100 \mathrm{~m}$ in the equatorial region than away from the equator (2.1 to 3.7). Below that depth no difference between regions was observed.

The mean vertical profiles of $\mathrm{chl}$ a/phaeo ratio for the 3 size-fractions are shown in Fig 7 . Ratios ranged from 0.4 to 1.5 for the $>10 \mu \mathrm{m}$ and from 1 to 1.9 for the 10 to 1

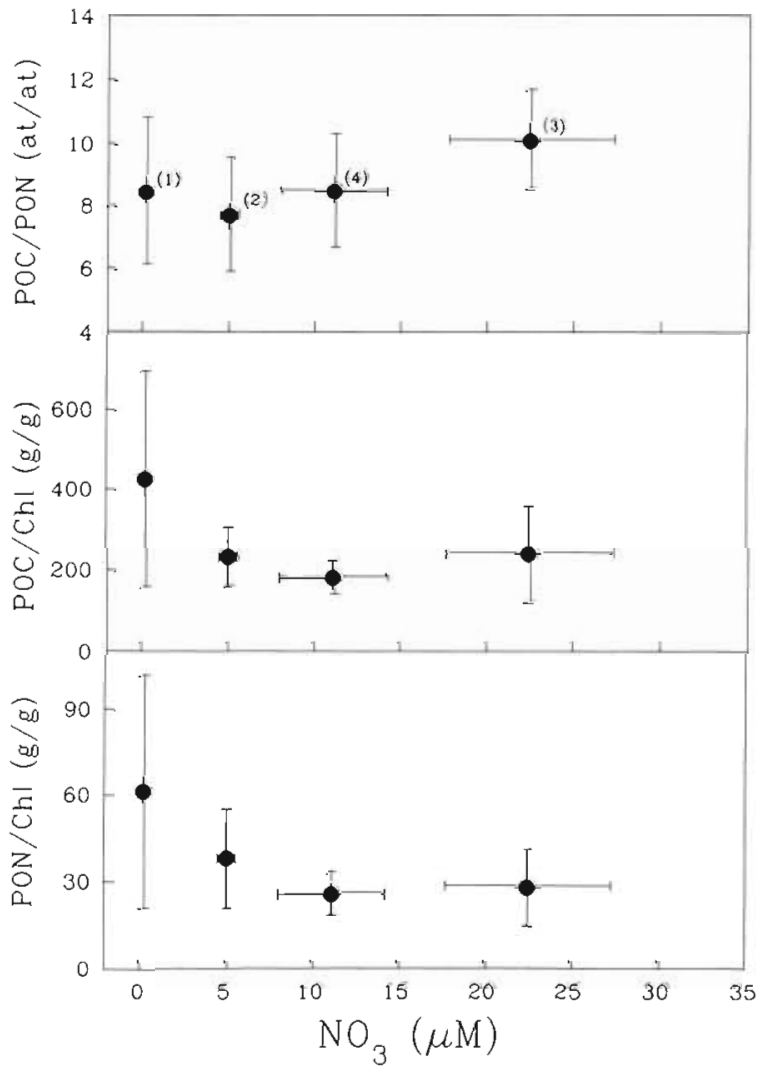

Fig. 4. Relationship between nitrate concentration and ratios of $\mathrm{POC} / \mathrm{PON}, \mathrm{POC} / \mathrm{chl}$ and PON/chl. Values represent the mean ratio and the standard error of: (1) the upper euphotic zone outside the equatorial region, (2) this level within the equatorial region, (3) the lower euphotic zone outside the equatorial region, and (4) this level within the equatorial region 
$\mu \mathrm{m}$ size-fraction, while the $<1 \mu \mathrm{m}$ fraction ranged from 0.4 to 3.8. In the latter fraction higher ratios were observed at the surface layer, decreasing with depth, until values similar to those of the $>10 \mu \mathrm{m}$ size fraction were observed (below $80 \mathrm{~m}$ ). This pattern indicates that for particles $>1 \mu \mathrm{m}$ in size, the vertical distribution of phaeopigment was similar to the vertical distribution of chl $a$, whereas for the $<1 \mu \mathrm{m}$ size a different vertical distribution existed. Thus, the vertical variation in chl a/phaeo ratios between regions was due predominantly to variations within the $<1 \mu \mathrm{m}$ size-fraction.

\section{DISCUSSION}

The concentrations of $\mathrm{POC}$ and $\mathrm{PON}$ observed in this study were within the range of values found in earlier studies of the equatorial Pacific (Wangersky 1976,

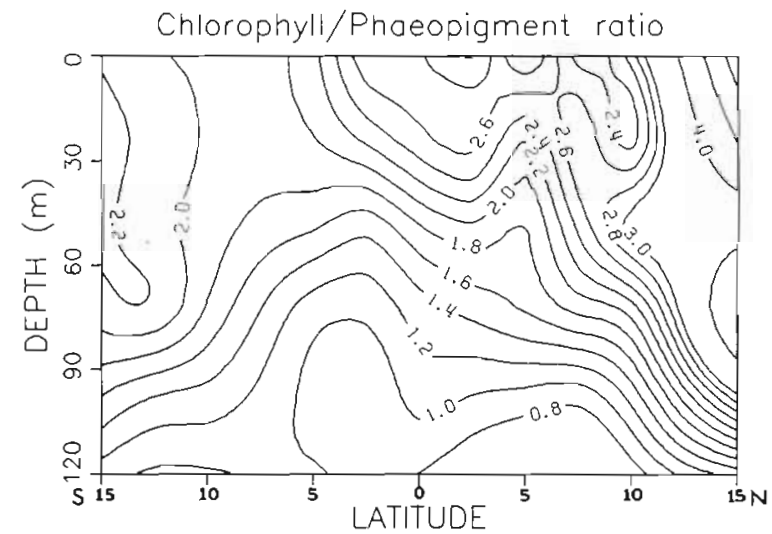

Fig. 5. Vertical section of chl a/phaeopigment ratio along the cruise track. Longitudinal variations between stations were ignored
Eppley et al. 1991), and around twice the values typically observed in the North Pacific gyre (Gordon 1971, Sharp et al. 1980, Eppley et al. 1988). The observed increase in POC and PON concentration at the equator, where nutrients were high, was similar to the pattern previously shown for chl a concentration and primary productivity (Feña et al. 1990). Although POC and PON concentrations were higher at the equator, the differ-

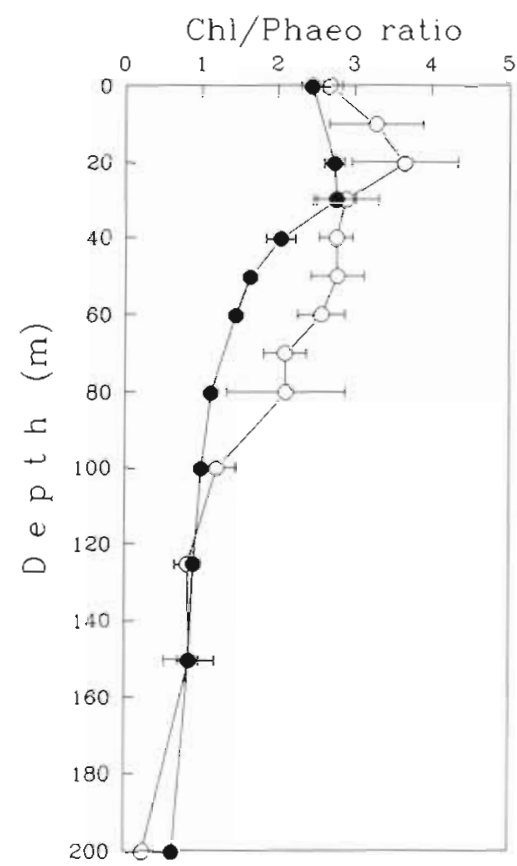

Fig. 6. Vertical distribution of the mean chl a/phaeopigment ratio at the equatorial region $(\bullet)$ and outside the equatorial region (o) and its standard error

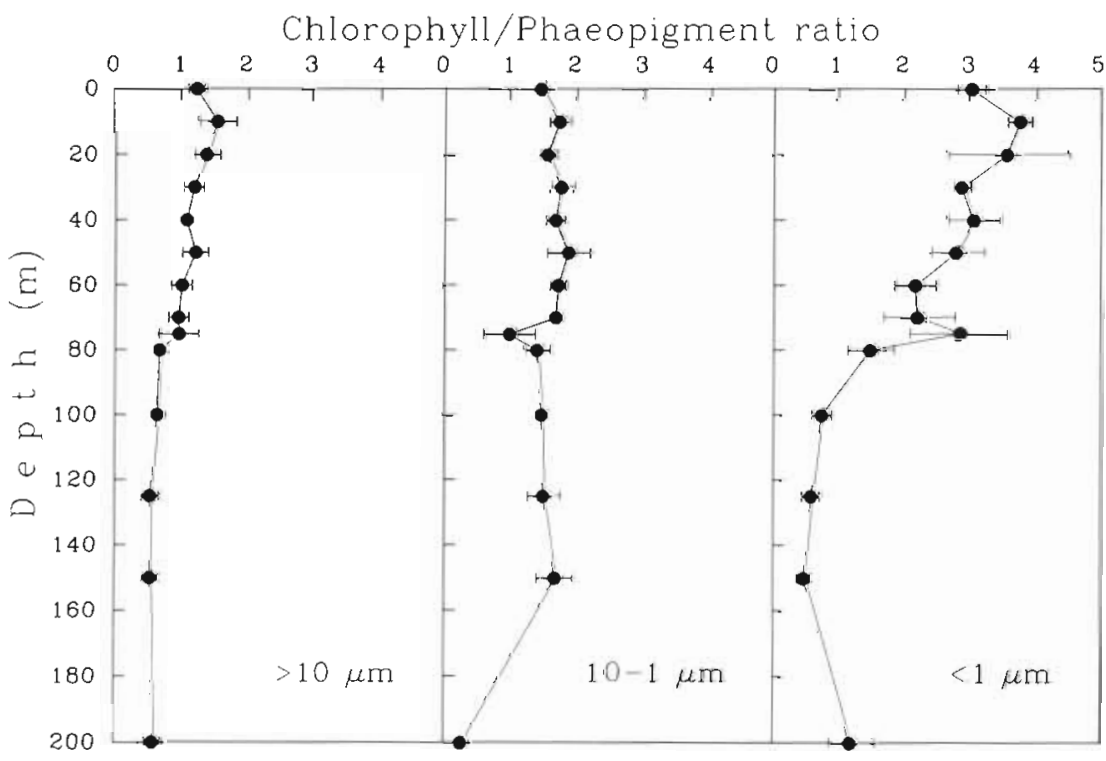

Fig. 7. Vertical distribution of the mean chl a/phaeopigment ratio in the different size fractions and its standard error ( $\mathrm{n}=$ 120) at all stations along the transect 
ences were less than 2-fold. Given the potential importance of the equatorial Pacific upwelling region to global new production (Chavez \& Barber 1987), biological properties varied much less than might be expected across this region.

Within the resolution of the bottle casts, maxima in suspended particulate matter in the euphotic zone were observed near the SCM layer in the equatorial region, but this increase was less than that of $\mathrm{chl} a$. Therefore, although part of the increase in chl $a$ at this depth may have been due to an increase in phytoplankton standing stock (particularly at the equatorial region), most of it was probably due to a higher content of chl in the cells at the SCM than at the upper layer. Similarly, in a transect across the equatorial Pacific at $150^{\circ} \mathrm{W}$, Pak et al. (1988) concluded that the vertical distribution of chl was predominantly caused by photoadaptation of cells, although a particle maximum was observed near the depth of the SCM within the latitude of equatorial upwelling. Moreover, Bienfang et al. (1983) based on experimental and modelling results also concluded that shade adaptation alone could account for the SCM in subtropical waters. In contrast, Eppley et al. (1991) found a uniform vertical distribution of both POC and PON over the euphotic zone in the same region. In the equatorial Atlantic region, a subsurface particulate maximum has also been observed (Herbland \& Le Bouteiller 1983).

In the equatorial region, the SCM was located at around 40 to $60 \mathrm{~m}$ above the Equatorial Undercurrent in the 'high shear' zone (Carr et al. 1991). In this region diffusion can disperse cells faster avoiding the development of non-uniformities in biomass. Phytoplankton cells in this layer would have to be growing at a considerably higher rate than in the upper layer if the SCM were the result of a local increase in phytoplankton standing stock. Hence, as previously suggested, the observed vertical distribution of chl is most likely to be the result of photoadaptation which can increase the cellular chl content on shorter time scales (e.g. Cullen \& Lewis 1988).

Away from the equator, the average $\mathrm{POC} / \mathrm{chl}$ a ratio was greatest (Fig. 4) in the mixed layer and lowest at the bottom of the euphotic zone. Although this pattern is consistent with expected changes due to physiological adaptation, the values obtained were considerably greater than most $\mathrm{C} / \mathrm{chl}$ ratios for the living phytoplankton. This suggests a large component of heterotrophs and detritus within the suspended matter. Although high light levels in surface waters may cause low chl a/cell, a lack of trace metals such as Fe also might limit the chl synthesis of phytoplankton, resulting in variable POC/chl ratios (Rueter \& Ades 1987). In this study, the presence of a high and variable content of POC not covarying with chl was reflected in the lack of or low correlation coefficient found for POC or PON on chl $a$ and in particular for the $<1$ um size fraction. The low phytoplankton content in the POM found in this region is consistent with previous observations across $150^{\circ} \mathrm{W}$ (Eppley et al. 1991), where Synechococcus was found to be the most numerous component of phytoplankton, although it contributed no more than $6 \%$ of POC and less than $7 \%$ of PON.

Within the regions, a significant POC on chl regression was obtained only at the equatorial region. The slope found (178) was considerably higher than those reported previously for this region. Zeitzschel (1971), using phytoplankton carbon derived from microscopical measurements, found a phytoplankton $\mathrm{C} / \mathrm{chl}$ ratio of $67 \pm 43$ in the EASTROPAC area of the eastern tropical Pacific at $120^{\circ} \mathrm{W}$. Using the same method as the present study, but a different regression model (Model I instead of II), Eppley et al. (1991) found the slope of the POC/chl regression to be $58(\mathrm{w} / \mathrm{w})$ in the equatorial Pacific at $150^{\circ} \mathrm{W}$, and Herbland \& Le Bouteiller (1983) found a slope of 54 to 57 in the equatorial Atlantic. A detailed discussion of the limitations of the regression approach was given by Banse (1977).

$\mathrm{C} / \mathrm{N}$ ratios for the suspended matter (5.7) in the euphotic zone were intermediate between the values obtained in the equatorial Pacific at $150^{\circ} \mathrm{W}$ (C/N 5.0; Eppley et al. 1991), and those from the equatorial Atlantic ( $\mathrm{C} / \mathrm{N} 6$ and 6.1 ; Herbland \& Le Bouteiller 1983), and within the values observed in several oceanic regions (Copin-Montegut \& Copin-Montegut 1983). All these values are significantly lower than the ratio of 8.9 found in the Panama Basin region (Murray et al. 1989). The increase in the $\mathrm{C} / \mathrm{N}$ ratio for particulate material below the upper euphotic zone (Fig. 4) suggests some preferential removal of $\mathrm{N}$ relative to $\mathrm{C}$ by recycling process within the lower layer or, alternatively, the vertical introduction of small-sized, detritusrich water from below.

The quotient POC/total ${ }^{14} \mathrm{C}$ production can be used to estimate POC residence time (Eppley et al. 1983). Using the productivity values previously reported for this transect (Peña et al. 1990), we obtained an average residence time of 6 to $7 \mathrm{~d}$ in the equatorial region and nearly $14 \mathrm{~d}$ away from the equator. Values similar to these have been obtained in the equatorial Pacific across $150^{\circ} \mathrm{W}$ (Eppley et al. 1991). The shorter residence time at the equatorial upwelling region indicates a faster removal of suspended particles in this region. Phytoplankton cells can be directly removed from the euphotic zone by lateral advection and sinking, and indirectly by zooplankton grazing.

In the equatorial Pacific region, particle losses due to advection and sinking do not seem to be the main mechanisms of removal. Equatorial divergence can 
replace surface waters only on longer time scales (Lewis et al, unpubl.). Moreover, in this region, as well as in the equatorial Atlantic, size-fractionation of chl has shown the dominance of small phytoplankton cells (Herbland et al. 1985, Chavez 1989, Peña et al. 1990) with negligible settling velocities (Bienfang \& Harrison 1984). Results from this study confirmed the dominance of small particles in this region, since most of the POC and PON concentrations in the mixed layer and SCM depth consisted of particles smaller than $10 \mu \mathrm{m}$. Therefore, zooplankton grazing seems to be the most reasonable explanation for phytoplankton biomass losses here. The lack of seasonality in the equatorial waters would imply a similar lack of seasonality in microheterotrophs, and should allow a closer coupling between phytoplankton and zooplankton than in more temperate populations. This should increase the effective control of phytoplankton populations by grazing.

It has been suggested that chl degradation products, phaeopigments, sampled in the water column can be used as a measure of grazing pressure (Lorenzen 1965. 1967). Considering that probably the major source of phaeopigments is grazing by zooplankton (Lorenzen 1967, SooHoo \& Kiefer 1982), increased amounts of phaeopigments relative to $\mathrm{chl} a$ indicate a higher herbivorous grazing pressure, although some production within senescent cells also occurs. We found lower $\mathrm{chl} a$ /phaeo ratios in the upper layer of the equatorial region (Fig. 5) suggesting higher grazing rates than away from the equator. Phaeopigments measured in routine pigment samples represent a net result of grazing and photooxidation on short time scales (Yentsch 1965, Lorenzen 1976, SooHoo \& Kiefer 1982, Welschmeyer \& Lorenzen 1985). According to SooHoo \& Kiefer's model (1982) of grazing and photooxidation in the upper layer, we have estimated that more than $86 \%$ of primary production is grazed by zooplankton, using average light conditions observed in the first $40 \mathrm{~m}$ (4.2 $\mathrm{mE} \mathrm{cm}^{-2} \mathrm{~d}^{-1}$ ) and a growth rate of $0.7 \mathrm{~d}^{-1}$ (Cullen et al. 1991).

Several authors (Yentsch 1965, Lorenzen 1967, Gibbs 1979, Vernet \& Lorenzen 1987) have recognized that the presence of chl $b$ may cause overestimates of phaeopigments and underestimates of chl a determined by the fluorometric technique and, therefore, would cause an overestimation of zooplankton grazing as estimated previously. In tropical waters chl $b$ has been found to be considerable at depth, whereas near the surface only traces have been observed (Gieskes \& Kraay 1986). Since, in this study, the average chl al phaeo ratio found in the first $40 \mathrm{~m}$ was used in the estimation of zooplankton grazing, the effect due to the presence of chl $b$ is expected to be small. Furthermore, we have found that the vertical distribution of the ratio chl a/phaeo varies among the different size-fractions; only in the $<1 \mu \mathrm{m}$ fraction did the chl/phaeo ratios decrease with depth. This could be due to the presence of green algae and prochlorophytes, which contain chl $b$ (Chisholm et al. 1988), in the SCM depth as observed in the Pacific Ocean and in the western equatorial Pacific (Takahashi \& Hori 1984, Everitt et al. 1990). In the upper layer, considerably higher ratios were found in the $<1 \mu \mathrm{m}$ fraction than in the other size fractions. This could be the result of a lower grazing pressure over this size fraction or that the fecal pellets of microzooplankton are bigger than this size.

Because feces of macrozooplankton are not effectively or quantitatively sampled by water bottles, the vertical distribution of phaeopigment corresponds more to features associated with smaller particles processed by micro- and nanozooplankton. Larger fecal material can be retained in the upper layer only if the fecal pellets are fragile and fragmented easily. However, due to its small size and low or negligible sinking rate, the pigmented fecal debris of microzooplankton herbivores would be expected to contribute to the pool of suspended phaeopigments and consequently would not be sampled by sediment traps (SooHoo \& Kiefer 1982, Welschmeyer \& Lorenzen 1985). As a consequence of the close coupling between producers and microzooplankton grazers we hypothesize to hold in the equatorial Pacific region, this suspended fraction may be very important to carbon flux out of the euphotic zone and should be considered in future models of the region.

The estimation of primary production from satellite chl data requires appropriate light-production models in conjunction with information about the total pigment content in the water column and its vertical distribution. Morel \& Berthon (1989) have distinguished several trophic situations according to the surface chl concentration, representing waters from very oligotrophic to very eutrophic. For each trophic category they obtain a mean vertical profile and an average value of the ratio $\mathrm{chl} a$ to (chl a + phaeo). In their analysis, the ratio decreases from eutrophic systems to oligotrophic waters and it also seems to be constant with depth. In contrast, in this study, the ratio increased from the more eutrophic equatorial region to outside this region (Fig. 6) and the value varied with depth. Moreover, although a similar vertical profile of chl has been observed, the SCM seems to be a poor indicator of phytoplankton biomass at the equatorial. Therefore, the equatorial Pacific region seems to be different from other regions and these differences should be considered when remote estimations of production are attempted. Particularly important is the ratio chl a to (chl a + phaeo) which responds almost linearly to the production estimates in Morel \& Berthon's model (1989). 
Acknowledgements. We thank D. Barber, R. Palmer and S. McLean for assistance at sea, and David Bird for his helpful comments on the manuscript. This research was supported by the National Science and Engineering Research Council, Strategic Grant Program (Canada)

\section{LITERATURE CITED}

Banse, K. (1977). Determining the carbon-to-chlorophyll ratio of natural phytoplankton. Mar. Biol. 41: 199-212

Betzer, P. R., Showers, W. J., Laws, E. A., Winn, C. D., DiTullio, G. R., Kroopnick, P. M. (1984). Primary productivity and particle fluxes on a transect of the equator at $135^{\circ} \mathrm{W}$ in the Pacific Ocean. Deep Sea Res. 31: 1-11

Bienfang, P., Szyper, J., Laws, E. (1983). Sinking rate and pigment responses to light-limitation of a marine diatom: implications to dynamics of chlorophyll maximum layers. Oceanol. Acta 6: 55-62

Bienfang, P. K., Harrison, P. J. (1984). Sinking-rate response of natural assemblage of temperate and subtropical phytoplankton to nutrient depletion. Mar. Biol. 83: 293-300

Carr, M. E., Oakey, N. S., Jones, B., Lewis, M. R. (1991). Hydrographic patterns and vertical mixing in the equatorial Pacific along $150^{\circ} \mathrm{W}$. J. geophys. Res. (in press)

Chavez, F. P. (1989). Size distribution of phytoplankton in the central and eastern tropical Pacific. Global Biochem. Cycles 3: 27-35

Chavez, F. P., Barber, R. T (1987). An estimate of new production in the equatorial Pacific. Deep Sea Res. 34: 1229-1243

Chisholm, S. W., Olsen, R. J., Zettler, E. R., Goericke, R., Waterbury, J. B., Welschmeyer, N. A. (1988). A novel, freeliving prochlorophyte abundant in the oceanic euphotic zone. Nature, Lond. 334 : 340-343

Copin-Montegut, C., Copin-Montegut, G. (1983). Stoichiometry of carbon, nitrogen, and phosphorus in marine particulate matter. Deep Sea Res. 30: 31-46

Cullen, J. J., Lewis, M. R. (1988). The kinetics of algal photoadaptation in the context of vertical mixing. J. Plankton Res. 10: 1039-1063

Cullen, J. J., Lewis, M. R., Davis, C. O., Barber, R. T. (1991). Photosynthetic characteristics and estimated growth rates of phytoplankton in the equatorial Pacific. J. geophys. Res. (in press)

Dugdale, R. C., Goering, J. J. (1967). Uptake of new and regenerated forms of nitrogen in primasy productivity. Limnol. Oceanogr. 12: 196-206

Eppley, R. W., Chavez, F. P., Barber, R. T. (1991). Standing stocks of particulate carbon and nitrogen in the equatorial Pacific at $150^{\circ} \mathrm{W}$. J. geophys. Res. (in press)

Eppley, R. W., Peterson, B. J. (1979). Particulate organic matter flux and planktonic new production in the deep ocean. Nature, Lond. 282: 677-680

Eppley, R. W., Renger, E. H., Betzer, P. R. (1983). The residence time of particulate organic carbon in the surface layer of the ocean. Deep Sea Res. 30: 311-323

Eppley, R. W., Swift, E., Redalje, D. G., Landry, M. R., Haas, L. W. (1988). Subsurface chlorophyll maximum in AugustSeptember 1985 in the CLIMAX area of the North Pacific. Mar. Ecol. Prog. Ser. 42: 289-301

Everitt, D. A. Wright, S. W., Volkman, J. K., Thomas, D. P., Lindstrom, E. J. (1990). Phytoplankton community compositions in the western equatorial Pacific determined from chlorophyll and carotenoid pigment distributions. Deep Sea Res. 37: 975-997

Gibbs, C. F. (1979). Chlorophyll $b$ interference in the fluorometric determination of chlorophyll $a$ and 'phaeopigments' Aust. J. mar. Freshwat. Res. 30: 597-606

Gieskes, W. W. C., Kraay, G. W. (1986). Floristic and physiological differences between the shallow and the deep nanoplankton community in the euphotic zone of the open tropical Atlantic revealed by HPLC analysis of pigments. Mar. Biol. 91: 567-576

Gordon, D. C. Jr (1971). Distribution of particulate organic carbon and nitrogen at an oceanic station in the central Pacific. Deep Sea Res. 18: 1127-1134

Herbland, A., Le Bouteiller, A. (1981). The size distribution of phytoplankton and particulate organic matter in the equatorial Atlantic Ocean: importance of ultraseston and consequences. J. Plankton Res. 3:659-673

Herbland, A., Le Bouteiller, A. (1983). Dynamique du phytoplancton et matiére organique particulaire dans la zone euphotique de l'Atlantique Equatorial. Mar. Biol. 72: 265-278

Herbland, A., Le Bouteiller, A., Raimbault, P. (1985). Sizestructure of phytoplankton biomass in the equatorial Atlantic Ocean. Deep Sea Res. 32: 819-836

Holm-Hansen, O., Lorenzen, C. J., Holmes, R. W., Strickland, J. D. H. (1965). Fluorometric determination of chlorophyll. J. Cons. perm. int. Explor. Mer 30: 3-15

Laws, E. A., Archie, J. W. (1981). Appropriate use of regression analysis in marine biology. Mar. Biol. 65: 13-16

Lorenzen, C. J. (1965). A note on the chlorophyll and pheophytin content of the chlorophyll maximum. Limnol. Oceanogr. 10: 482-483

Lorenzen, C. J. (1967). Vertical distribution of chlorophyll and phaeopigments: Baja California. Deep Sea Res. 14 735-745

Lorenzen, C. J. (1976). Primary production in the sea. In: Cushing, D. H., Walsh, J. J. (eds.) The ecology of the seas. Saunders, London, p. 173-185

Minas, H. J., Minas, M. (1986). Productivity in upwelling areas deduced from hydrographic and chemical fields. Limnol. Oceanogr. 31: 1182-1206

Morel, A., Berthon, J. F. (1989). Surface pigments, algal biomass profiles, and potential production of the euphotic layer: relationships reinvestigated in view of remote-sensing applications. Limnol. Oceanogr. 34: 1545-1562

Muray, J. W., Downs, J. N., Strom, S., Wei, C., Jannasch, H. W. (1989). Nutrient assimilation, export production and ${ }^{234} \mathrm{Th}$ scavenging in the eastern equatorial Pacific. Deep Sea Res. 36: 1471-1489

Pak, H., Kiefer, D. A., Kitchen, J. C. (1988). Meridional variations in the concentration of chlorophyll and microparticles in the North Pacific Ocean. Deep Sea Res. 35: 1151-1171

Peña, M. A., Lewis, M. R., Harrison, W. G. (1990). Primary productivity and size structure of phytoplankton biomass on a transect of the equator at $135^{\circ} \mathrm{W}$ in the Pacific Ocean. Deep Sea Res. 37: 295-315

Rueter, J. G., Ades, D. R. (1987). The role of iron nutrition in photosynthesis and nitrogen assimilation in Scenedesmus quadricauda (Chlorophyceae). J. Phycol. 23: 452-457

Sharp, J. H., Perry, M. J., Renger, E. H., Eppley, R. W. (1980). Phytoplankton rate processes in the oligotrophic waters of the central North Pacific Ocean. J. Plankton Res. 2: 335-353

SooHoo, J. B., Kiefer, D. A. (1982). Vertical distribution of phaeopigments - II. Rates of production and kinetics of photooxidation. Deep Sea Res. 29: 1553-1563

Strickland, J. D. H., Parsons, T. R. (1972). A practical handbook of sea water analysis. Can. Bull. Fish. Aquat. Sci. 167

Takahashi, M., Hori, T (1984). Abundance of picoplankton in the subsurface chlorophyll maximum layer in subtropical and tropical waters. Mar. Biol. 79: 177-186 
Thomas, W. H. (1979). Anomalous nutrient chlorophyll interrelationship in the offshore eastern tropical Pacific Ocean. J. mar Res. 37. 327-335

Vernet, M., Lorenzen, C. J. (1987). The presence of chlorophyll $b$ and the estimation of phaeopigments in marine phytoplankton. J. Plankton Res. 9: 255-265

Walsh, J. J. (1976). Herbivory as a factor in patterns of nutrient utilization in the sea. Limnol. Oceanogr. 21.1-13

Wangersky, P. J. (1976). Particulate organic carbon in the Atlantic and Pacific oceans. Deep Sea Res. 23: 457-465

This article was submitted to the editor
Welschmeyer, N. A., Lorenzen, C. J. (1985). Chlorophyll budgets: zooplankton grazing and phytoplankton growth in a temperate fjord and the Central Pacific Gyres. Limnol. Oceanogr. 30: 1-21

Yentsch, C. S. (1965). Distribution of chlorophyll and pheophytin in the open ocean. Deep Sea Res. 12: 653-666 Zeitzschel, B. (1971). Primärproduktion und Phytoplanktonökologie in östlichen tropischen Pazifik (Ergebnisse der EASTROPAC-Expedition 1967/1968). Christian Albrechts Universität Kiel, Habilitationsschrift

Manuscript first received: December 5, 1990 Revised version accepted: February 21, 1991 